\title{
End-use related physical and mechanical properties of selected fast-growing poplar hybrids (Populus trichocarpa $\times$ P. deltoides)
}

\author{
Lieven De Boever, Dries Vansteenkiste, Joris Van Acker, Marc Stevens*
}

Department of Forest and Water Management, Laboratory of Wood Technology, Ghent University, Coupure Links 653, 9000 Ghent, Belgium

(Received 7 August 2006; accepted 18 January 2007)

\begin{abstract}
This study focused on physical and mechanical properties of fast-growing poplar clones in relation to potential end uses with high added value. A total of 14 trees from three different clones, all P. trichocarpa $\times$ deltoides $(\mathrm{T} \times \mathrm{D})$ hybrids, were felled in a poplar plantation in Lille $($ Belgium $)$ : six 'Beaupré', four 'Hazendans' and four 'Hoogvorst'. Growth rate was found to have no significant influence on the physical mechanical properties. Although the investigated clones are genetically closely related, important variations in physical and mechanical properties were observed. Specific features such as spatial distribution of tension wood and dimensional stability are the main quality factors. It was concluded that 'Beaupré' is suitable for a wide range of high value added applications, such as plywood or construction wood. 'Hazendans' and 'Hoogvorst' will need adapted technology in processing. Further research is needed to characterize clonally induced variation in properties and to assess adequate processing strategies for multiclonal poplar stands.
\end{abstract}

Populus trichocarpa $\times$ P. deltoides / physical properties / mechanical properties / veneer / plywood

Résumé - Propriétés physiques et mécaniques d'hybrides de peupliers à croissance rapide en fonction de l'aptitude à l'emploi. Cette étude porte sur les caractéristiques physiques et mécaniques du bois de clones de peupliers à croissance rapide, en fonction de l'aptitude à l'emploi. Quatorze arbres ont été étudiés, provenant d'une plantation de peuplier à Lille (Belgique), appartenant à trois hybrides différents de P. trichocarpa $\times$ deltoides, à savoir six "Beaupré", quatre "Hazendans" et quatre "Hoogvorst". Les caractéristiques de croissance n'ont pas affecté de manière significative les propriétés physiques et mécaniques. Bien que les clones étudiés soient génétiquement rapprochés, des variations importantes ont été constatées dans les propriétés physiques et mécaniques. Des caractéristiques spécifiques telles que la distribution spatiale du bois de tension et la stabilité dimensionnelle du bois sont des propriétés importantes affectant sur la qualité du produit final. On peut conclure que le bois de "Beaupré" est apte à la fabrication de panneaux contreplaqués et de bois de sciage. Une adaptation de la technologie de transformation sera nécessaire pour les clones 'Hazendans' et 'Hoogvorst'. Des recherches approfondies seront requises afin d'évaluer la variabilité induite par l'effet clonal ainsi que pour identifier des stratégies adaptées à la transformation du bois de peuplements multiclonaux.

Populus trichocarpa $\times$ P. deltoides / bois de tension / bois de cour / propriétés physico-mécanique / contreplaqué

\section{INTRODUCTION}

In spite of criticism against monocultures of poplar from the ecological point of view, timber and biomass from poplar plantations remain one of the most important resources for the wood industry in various countries. As a fast-growing species, poplar enhances the possibility to cover increasing wood demands.

Since 1948, research performed at the former Institute for Poplar Cultivation (currently the Institute for Nature and Forest Research - INBO,Geraardsbergen, Belgium), has played a leading role in selection and breeding of poplar, not only for vigour, but also in terms of adaptation to climate conditions as well as disease resistance. Due to recent shifts in resistance to rust disease and changing industrial demands, new selected poplar hybrids had to be introduced. This necessitates continuous monitoring of wood quality with respect to possible enduses.
Wood quality is to a large extent genetically determined [26]. Moreover, wood is formed by a living individual with cyclic activity, resulting in an annually fluctuating growth in width and height, which is dependent on site conditions and influenced by age. Consequently, wood properties can show a certain variation between and within individuals of the same clone in poplar. This may affect the overall wood quality and its final utilisation.

The produced poplar wood is usually light, with a density between 360 and $540 \mathrm{~kg} / \mathrm{m}^{3}$, and quite strong resulting in a high strength-density ratio. The latter is an important feature with regard to construction purposes. Modulus of elasticity to density ratios of 22 to 27 do position poplar between softwoods (values around 30) and other hardwood species (values around 20) [12, 20,21].

In poplar wood, the physical and mechanical properties tend to display clone-to-clone as well as inter- and intra-tree variations. Density is commonly high at the bottom of the tree, decreases to a minimum at mid-height, then increases again near the top of the merchantable stem $[3,8,18,24]$. Density

* Corresponding author: Lieven.DeBoever@UGent.be 
Table I. Genetic background of investigated clones with dendrometrical characteristics for selected trees and total stand; mean radial increment and radial increment of last 10 years $(\mathrm{cm})$, circumference at $\mathrm{BH}(\mathrm{cm})$ and total tree height $(\mathrm{m})$ with standard deviations.

\begin{tabular}{|c|c|c|c|c|}
\hline & Clone & Beaupré & Hazendans & Hoogvorst \\
\hline & Mother & V235 & V471 & V235 \\
\hline & Father & S1-173 & S620-225 & S620-225 \\
\hline & \# selected trees & 6 & 4 & 4 \\
\hline \multirow[t]{4}{*}{ Selected trees } & Mean radial increment $(\mathrm{cm})$ & $1.13 \pm 0.14$ & $1.05 \pm 0.14$ & $1.44 \pm 0.23$ \\
\hline & Mean radial increment last 10 years $(\mathrm{cm})$ & $1.02 \pm 0.15$ & $1.01 \pm 0.14$ & $1.42 \pm 0.19$ \\
\hline & Mean circumference $(\mathrm{cm})$ & $151 \pm 21$ & $141 \pm 23$ & $187 \pm 27$ \\
\hline & Total tree height $(\mathrm{m})$ & $28.9 \pm 3.7$ & $28.0 \pm 2.2$ & $31.7 \pm 3.3$ \\
\hline \multirow[t]{2}{*}{ Stand } & Mean circumference $(\mathrm{cm})$ & $149 \pm 25$ & $149 \pm 27$ & $185 \pm 23$ \\
\hline & Total tree height $(\mathrm{m})$ & $29.7 \pm 4.0$ & $28.6 \pm 3.5$ & $31.2 \pm 4.5$ \\
\hline
\end{tabular}

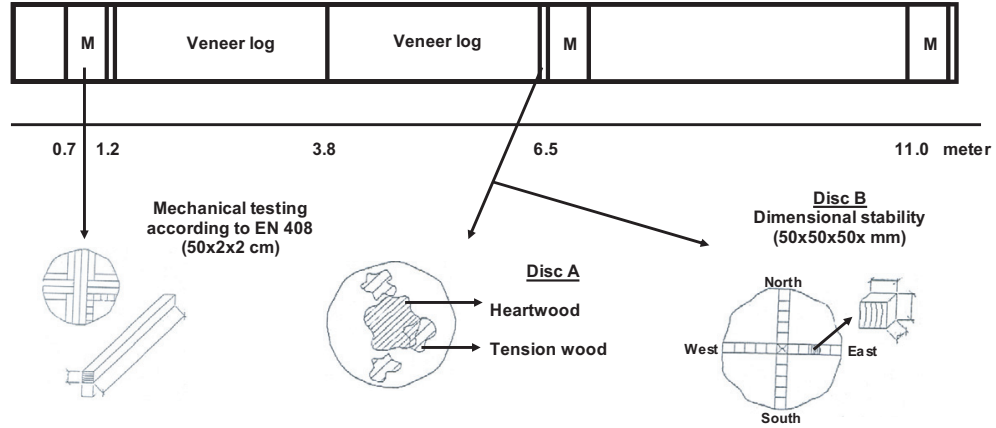

Figure 1. Partitioning of the trees in relation to the different specimens required for testing.

variations between clones have been described by different authors. Peszlen [18] could not find a significant difference among 10 to 15 -year-old clones of $P$. deltoides $\times$ nigra, while Hernández et al. [10] examined 9-year-old $P$. deltoides $\times n i$ gra and found a significant clone-to-clone variation. Earlier comparison of fast-growing Belgian poplar clones proved that major variations exist [21,22]. Beaudoin et al. [3] and Hernández et al. [10] pointed out significant but weak negative correlations between wood density or mechanical properties and growth rate in $P$. deltoides $\times$ nigra.

The objective of this study is to evaluate the variability in selected physical and mechanical properties of new inter-American poplar clones (P. trichocarpa $\times$ deltoides $)$. As poplar plantations are a local source of wood which take away pressure from native forests, this also contributes in producing high value added products with extended service life.

\section{MATERIALS AND METHODS}

A total of 14 trees from three different clones, all $P$. trichocarpa $\times$ deltoides $(\mathrm{T} \times \mathrm{D})$ hybrids, were felled in a poplar plantation in Lille (Belgium): six 'Beaupré', four 'Hazendans' and four 'Hoogvorst'. The trees had all grown on sandy to loamy sand soils with a poor drainage, in adjacent stands with a planting distance of $8 \times 8 \mathrm{~m}$. Trees were selected in respect of their diameter at breast height so that it was representative of the diameter distribution in the different clonesite combinations. Trees that were suspected to suffer from border effects, e.g. standing near the border of the site or near a dead tree, were excluded. The trees were all 21 years old and their circumference at breast height ranged from 141 to $187 \mathrm{~cm}$. Table I gives an overview of genetic background and stand characteristics of the three selected poplar clones.

The trees were sawn into stem discs, logs and beams, depending on the different tests to be performed, according to the scheme shown in Figure 1. To assess the basic technical quality of each clone, tension wood and (false) heartwood proportion, density, dimensional stability, modulus of elasticity (MOE) and modulus of rupture (MOR) have been quantified at three different heights.

For evaluating the amounts of heartwood and tension wood, density and the shrinkage upon drying of the wood, two sets of stem discs were taken at $1.2 \mathrm{~m}, 6.5 \mathrm{~m}$ and $11.5 \mathrm{~m}$ (Fig. 1). The first set of discs (A) was used to determine amounts of tension wood and heartwood as well as for the determination of the growth characteristics (tree ring width); the second set (B) was used for sampling test specimens to determine wood density and dimensional stability. To identify the tension wood zones the surfaces of the cross sections were stained with a zink-chloride-iodine solution. The cumulative area of the tension wood zones was then measured digitally and expressed as a percentage of the cross-sectional area. A similar procedure was used for determining the readily visible dark coloured heartwood proportion. To calculate the amount of heartwood in the whole commercial stem, data were volume weighted by extrapolation of the surface measures.

In order to evaluate the spatial distribution of the individual tension wood areas, a two-parameter Weibull probability density 
function (pdf) was fitted to the data. In this case, an evaluation per clone was made of the likely occurrence of larger tension wood zones. The two-parameter Weibull distribution is described by a shape factor $\beta$ and a scale factor $\alpha$. Figure 2 shows the measured frequencies per class of tension wood proportions, as well as the fitted Weibull distribution. The fits were correlated well with the measured data and statistical significant $(p=0.01)$ for all clones.

In order to quantify wood density and the dimensional stability of timber, cubic specimens with $30 \mathrm{~mm}$ ribs, were cut out of the stem discs B according to the major wind directions (Fig. 1). The specimens were first measured in fresh condition and then were subjected to consecutive changes in relative air humidity $(\mathrm{RH})$ in a climate room at $90 \% \mathrm{RH}$ over $60 \% \mathrm{RH}$ to $40 \% \mathrm{RH}$, all at $20{ }^{\circ} \mathrm{C}$ and finally to oven-dry state.

Density was calculated at different stages of moisture content. These data were used to determine correlations between shrinkage parameters and densities. Density was always expressed at equilibrium of a certain conditioning phase (As the mass to the volume at the specified RH). A weighted average (volume based) of the obtained densities at $60 \% \mathrm{RH}$ was compared to the weighted average based on the samples used for mechanical testing to validate the density measurements. The density values later on reported (Tab. III and Fig. 5) are density values determined at $60 \% \mathrm{RH}$. Mass was determined at an accuracy of $0.001 \mathrm{~g}$ while the dimensions were determined using a calliper with an accuracy of $0.01 \mathrm{~mm}$.

For the mechanical tests stem parts of $50 \mathrm{~cm}$ in length $(\mathrm{M})$ were taken at three different heights $(0.7 \mathrm{~m}, 6.6 \mathrm{~m}$ and $11.0 \mathrm{~m})$. The material was subsampled into test specimens of $50 \mathrm{~cm}$ axial length and a cross section of $2 \times 2 \mathrm{~cm}$ in accordance with EN 408. The specimens were sawn and subsequently planed parallel to the grain and the annual rings aligned with one side of the cross section. Every specimen received its own co-ordinate, so that the exact position in the stem remained known. The sawn pattern was designed to provide a maximal number of flawless test specimens at each height (Fig. 1). The number of test specimens per clone per height level ranges from 10 to 25 .

The $50 \times 2 \times 2 \mathrm{~cm}$ samples were conditioned at $60 \pm 2 \%$ relative humidity and $20 \pm 1{ }^{\circ} \mathrm{C}$. It took for all samples 5 weeks to reach the equilibrium state. The EMC at $60 \% \mathrm{RH}$ was $12.7 \%$ with a standard deviation of $0.6 \%$. The static edgewise modulus of elasticity (MOE) and the modulus of rupture (MOR) were determined by means of a 4-point bending test, according to EN 408. The knot-free specimens were loaded at the centre at a rate of $8 \mathrm{~mm}$ per min in order to reach a duration of the test of $300 \pm 120 \mathrm{~s}$.

Of each stem, two logs of $2.6 \mathrm{~m}$ were peeled using industrial equipment to evaluate veneer quality and, subsequently, plywood properties. The thickness of the veneer was $1.5 \mathrm{~mm}$. The logs were exactly measured using laser scanning technology, allowing to determine the centre points for optimal yield. The total amount of veneers produced allowed a first yield figure. Clipping losses related to edge trimming and defect elimination were also taken into account. After drying some veneers were rejected due to excessive crack formation or extreme waviness. As such, three quality classes were discerned. These quality classes were described by the commercial grading system of the peeling company. Next to the description of the discerned classes a parallel was made to the five quality classes used by EN 635-2. The A-quality is referring to closed veneers (absence of defects) (is comparable with the combined classes E and I of EN 635-2), whereas B-quality allows small defects (small checks or holes) to the extent that they can be technically repaired (is compa-

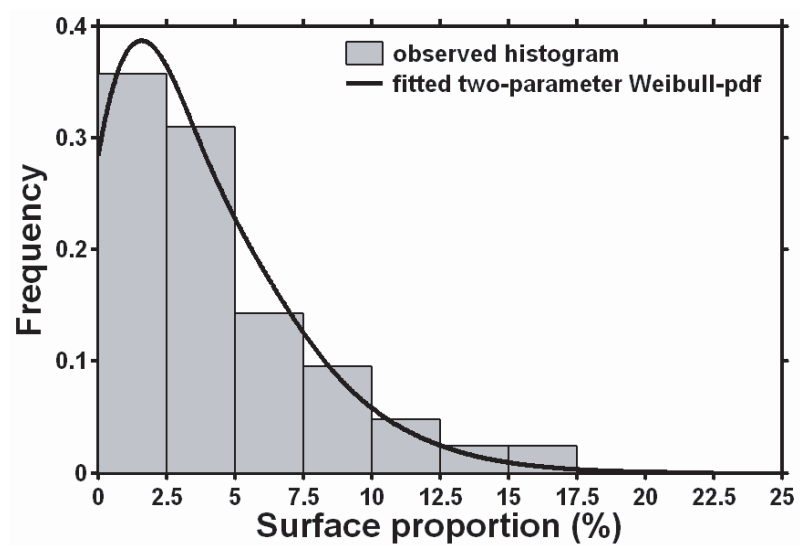

Figure 2. Example of observed histogram of tension wood surface proportions (classes of $2.5 \%$ ) and fitted two-parameter Weibull probability density function, for the clone 'Beaupré'.

rable with the combined classes II and III of EN 635-2). C/D-quality veneers contain larger defects and are used for the interior plies of the board only. The latter class is comparable to the quality class IV of the EN 635-2 standard.

Out of the top quality veneers (A and B classes), seven-layer plywoods were produced using an urea-formaldehyde glue. These boards were tested for density, MOE and MOR (in both veneer directions) according to EN 310. Per clone 10 samples (thickness $\times 500 \times 50 \mathrm{~mm}$ ) were tested per veneer direction.

In the result section, the significance of a statistical analysis is indicated by a number of asterisks (* $p=0.05$; ** $p=0.01$; *** $p=$ $0.001)$.

\section{RESULTS}

\subsection{Dendrometrical measurements}

Table I gives an overview of some selected dendrometrical features for the investigated clones. The radial as well as the height growth of 'Hoogvorst' are significantly ( $p=$ 0.05 ) higher than those of 'Beaupré' and 'Hazendans'. The growth profiles (results not presented) showed that the diameter growth culminates earlier for 'Beaupré and Hoogvorst (810 years) than for 'Hazendans' (12-15 years). The mean values given in table I are based on measurements at breast height only. Similar trends have been observed, however, higher in the stem.

\subsection{Heartwood and tension wood proportions}

Table II shows the proportions of heartwood and tension wood recorded for the three poplar clones.

A Duncan's multiple range test allowed determining significant clonal differences $(p=0.05)$ in average amounts of heartwood. This analysis shows that the amount of heartwood is significantly higher for 'Hazendans' $( \pm 40 \%)$ than for both 
Table II. Average heartwood and tension wood proportions (\%) at three different heights, as well as the volume weighted average with standard deviation and the minimum and maximum values.

\begin{tabular}{|c|c|c|c|c|}
\hline \multicolumn{5}{|c|}{ (a) Heartwood proportion } \\
\hline & Beaupré & Hazendans & Hoogvorst & Duncan ranking \\
\hline Height $1.2 \mathrm{~m}$ & 41.3 & 47.4 & 38.2 & aba \\
\hline $6.5 \mathrm{~m}$ & 20.0 & 37.5 & 26.3 & aba \\
\hline $11.5 \mathrm{~m}$ & 8.9 & 19.7 & 16.8 & baa \\
\hline Volume weighted average & 30.8 & 41.5 & 31.5 & aba \\
\hline Standard deviation & 5.1 & 7.3 & 6.3 & - \\
\hline Minimum & 4.6 & 14.1 & 12.4 & - \\
\hline Maximum & 48.6 & 54.6 & 51.3 & - \\
\hline \multicolumn{5}{|c|}{ (b) Tension wood proportions } \\
\hline & Beaupré & Hazendans & Hoogvorst & Duncan ranking \\
\hline Height $1.2 \mathrm{~m}$ & 16.5 & 19.1 & 19.7 & aaa \\
\hline $6.5 \mathrm{~m}$ & 9.8 & 8.9 & 8.6 & aaa \\
\hline $11.5 \mathrm{~m}$ & 8.5 & 7.3 & 7.2 & aаa \\
\hline Volume weighted average & 11.6 & 11.7 & 11.8 & aaa \\
\hline Standard deviation & 4.3 & 6.4 & 6.8 & - \\
\hline Minimum & 4.2 & 5.5 & 3.6 & - \\
\hline Maximum & 25.4 & 26.8 & 28.7 & - \\
\hline
\end{tabular}

'Beaupré' and 'Hoogvorst' $( \pm 30 \%)$. The proportion of heartwood decreases linearly with height. Highly significant linear regressions $(y=A x+B)$ were obtained for all clones ('Beaupré' $A=-3.8 ; B=52.0 ; R^{2}=0.95^{* *}$; 'Hazendans' $A=-2.6 ; B=60.0 ; R^{2}=0.83^{* *} ;$ 'Hoogvorst' $A=-3.2$; $\left.B=50.6 ; R^{2}=0.93 * *\right)$.

A Duncan multiple range test did not point out differences between the tension wood proportions (Tab. IIb) for the three clones, all having volume weighted average values around $12 \%$. At breast height, higher relative amounts of tension wood were observed. Higher in the stem no trend in tension wood occurrence could be distinguished.

Figure 3 represents for each clone individually the fitted two-parameter Weibull distribution of the surface proportion of individual tension wood zones. This graph shows that 'Hoogvorst' and 'Hazendans' have similar distributions compared to 'Beaupré'. The distributions cross at a surface proportion of an individual zone of $6.25 \%$.

The distribution of 'Beaupré' indicates that this clone has a bigger amount of smaller individual tension wood areas ( $85 \%$ of the tension wood zones $<6.25 \%$ ). 'Hoogvorst' and 'Hazendans' (respectively 55\% and 54\% $<6.25 \%$ ) have more tension wood zones of larger surface proportion. Therefore, the occurrence of larger zones is less likely in 'Beaupré' than in 'Hoogvorst' and 'Hazendans', or 'Beaupré' has more diffuse tension wood than 'Hoogvorst' and 'Hazendans'.

\subsection{Density, mechanical properties and dimensional stability}

Surface weighted densities for each height level as well as the total volume weighted density for the investigated clones

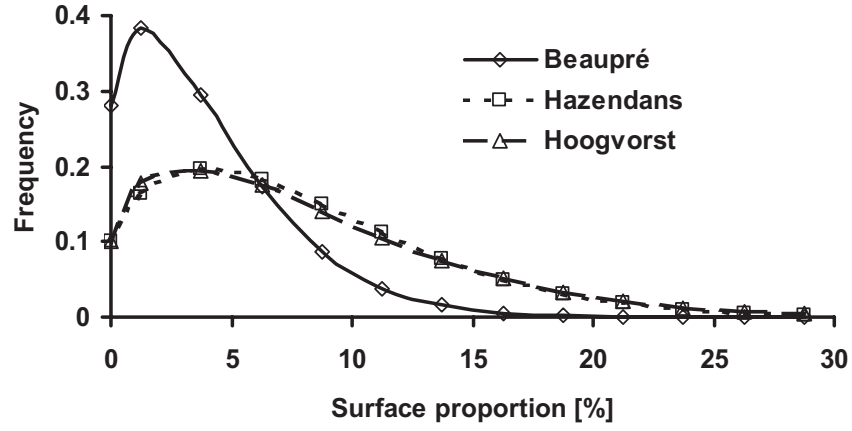

Figure 3. Fitted two-parameter Weibull pdf, showing the surface proportion distributions of individual tension wood zones for the investigated clones.

are reported in Table III. When density is calculated without a volume based weighing, the average values at the bottom height are 15 to $25 \mathrm{~kg} / \mathrm{m}^{3}$ lower. A similar trend is found for MOE (400 to $800 \mathrm{~N} / \mathrm{mm}^{2}$ lower) and MOR (5 to $15 \mathrm{~N} / \mathrm{mm}^{2}$ lower).

Density increases linearly $(y=A x+B)$ with height ('Beaupré' $A=10.9 ; B=356 ; R^{2}=0.95^{* *}$; 'Hazendans' $A=10.3 ; B=394 ; R^{2}=0.96 * *$ and 'Hoogvorst' $A=6.8$; $\left.B=362 ; R^{2}=0.96^{* *}\right)$. An analoguous trend as for density was observed in the results of the bending tests (MOR and MOE).

The specific strength (ratio of mechanical property and density) is highest for 'Beaupré' when stiffness is concerned, while 'Hoogvorst' has the highest ratio in terms of strength. This also provides a measure of suitability as construction timber. 
Table III. Surface weighted average values for density, modulus of elasticity and modulus of rupture at three different heights, as well as the volume weighted average, with standard deviation, minimum and maximum values.

\begin{tabular}{|c|c|c|c|c|}
\hline \multicolumn{5}{|c|}{ (a) Density $\left(\mathrm{kg} / \mathrm{m}^{3}\right)$} \\
\hline & Beaupré & Hazendans & Hoogvorst & Duncan ranking \\
\hline Height $0.7 \mathrm{~m}$ & 372 & 402 & 361 & aba \\
\hline $6.6 \mathrm{~m}$ & 433 & 453 & 391 & aab \\
\hline $11.0 \mathrm{~m}$ & 479 & 485 & 424 & aab \\
\hline Volume weighted average & 423 & 446 & 391 & $\mathrm{aab}$ \\
\hline Standard deviation & 19 & 33 & 32 & - \\
\hline Minimum & 339 & 371 & 335 & - \\
\hline Maximum & 507 & 510 & 461 & - \\
\hline \multicolumn{5}{|c|}{ (b) Modulus of elasticity $\left(\mathrm{N} / \mathrm{mm}^{2}\right)$} \\
\hline & Beaupré & Hazendans & Hoogvorst & Duncan ranking \\
\hline Height $0.7 \mathrm{~m}$ & 6732 & 6569 & 5314 & $a a b$ \\
\hline $6.6 \mathrm{~m}$ & 8100 & 7954 & 6577 & aab \\
\hline $11.0 \mathrm{~m}$ & 8802 & 9033 & 7692 & $\mathrm{aab}$ \\
\hline Volume weighted average & 7857 & 7783 & 6510 & aab \\
\hline Standard deviation & 544 & 337 & 280 & - \\
\hline Minimum & 6052 & 6150 & 4851 & - \\
\hline Maximum & 9472 & 9450 & 7916 & - \\
\hline \multicolumn{5}{|c|}{ (c) Modulus of rupture $\left(\mathrm{N} / \mathrm{mm}^{2}\right)$} \\
\hline & Beaupré & Hazendans & Hoogvorst & Duncan ranking \\
\hline Height $0.7 \mathrm{~m}$ & 53 & 60 & 62 & abb \\
\hline $6.6 \mathrm{~m}$ & 63 & 71 & 75 & $a b b$ \\
\hline $11.0 \mathrm{~m}$ & 70 & 78 & 86 & $\mathrm{abc}$ \\
\hline Volume weighted average & 62 & 69 & 74 & $\mathrm{abc}$ \\
\hline Standard deviation & 5 & 5 & 6 & - \\
\hline Minimum & 46 & 54 & 57 & - \\
\hline Maximum & 74 & 83 & 94 & - \\
\hline
\end{tabular}

A significant correlation $\left(R^{2}=0.86^{*}\right)$ was found between the average basic density measured at breast height and the overall basic density of the total merchantable stem (basic density of the total merchantable stem $=1.11 \times$ density at breast height), irrespective of the clone.

Table IV shows for two different intervals of relative air humidity $(\mathrm{RH})$ the global mean shrinkage in tangential and radial direction together with the shape factor (tangential shrinkage divided by radial shrinkage) and the mean volumetric shrinkage.

Stability (low shrinkage values) decreases with increasing height, following the trend of increasing density.

\subsection{Veneer quality - Density and mechanical properties of plywood}

Figure 4 gives an overview of the efficiency of the veneer processing as well as the different yield parameters. 'Hazendans' shows most trim clipping losses in peeling, due to its less cylindrical stem form. In 'Beaupré' a substantial lower amount of veneers is lost in the drying process. Table $\mathrm{V}$ gives more detailed information on the veneer quality and points out the different reasons for excluding veneer sheets.

The overall yield of veneer produced is significantly higher in 'Beaupré' than in the other clones. When the production of quality veneers (white veneers of grade A) is considered, major differences can be pointed out. 'Hazendans' and 'Hoogvorst' have very low yields of grade A veneers. 'Hoogvorst' shows a significantly lower yield of grade B veneers and produces a large amount of grade C/D veneers which are only suitable for the interior of plywood boards. All veneers of 'Hazendans' have a uniform white colour.

Only the A/B-quality veneers were used to produce plywood resulting in 3 to 5 panels $(1250 \times 2500 \mathrm{~mm})$ per clone. Table VI gives an overview of the density, modulus of elasticity and modulus of rupture for each clone. Both mechanical properties were tested perpendicular and parallel to the grain as described in EN 310. The average strength values of boards made of 'Hoogvorst' veneers are significantly lower than those of 'Hazendans' and 'Beaupré'. 
Table IV. Mean clonal shrinkage values (radial (R), tangential (T) and volumetric) and shape factor for two different intervals of relative air humidity and the multiple range statistics by Duncan.

(a) From $90 \%$ to $60 \%$ relative air humidity $(\%)$

\begin{tabular}{lllll}
\hline & Beaupré & Hazendans & Hoogvorst & Duncan ranking \\
\hline Radial shrinkage & 1.80 & 1.38 & 1.26 & abb \\
Tangential shrinkage & 4.02 & 3.12 & 3.39 & abb \\
Shape factor (T/R) & 2.23 & 2.26 & 2.69 & aab \\
Volumetric shrinkage & 5.81 & 4.51 & 4.65 & $\mathrm{abb}$ \\
\hline
\end{tabular}

(b) From $60 \%$ to $40 \%$ relative air humidity (\%)

\begin{tabular}{lllll}
\hline & Beaupré & Hazendans & Hoogvorst & Duncan ranking \\
\hline Radial shrinkage & 0.36 & 0.48 & 0.37 & aba \\
Tangential shrinkage & 0.60 & 1.01 & 0.65 & aba \\
Shape factor (T/R) & 1.67 & 2.11 & 1.76 & aba \\
Volumetric shrinkage & 0.97 & 1.48 & 1.03 & aba \\
\hline
\end{tabular}

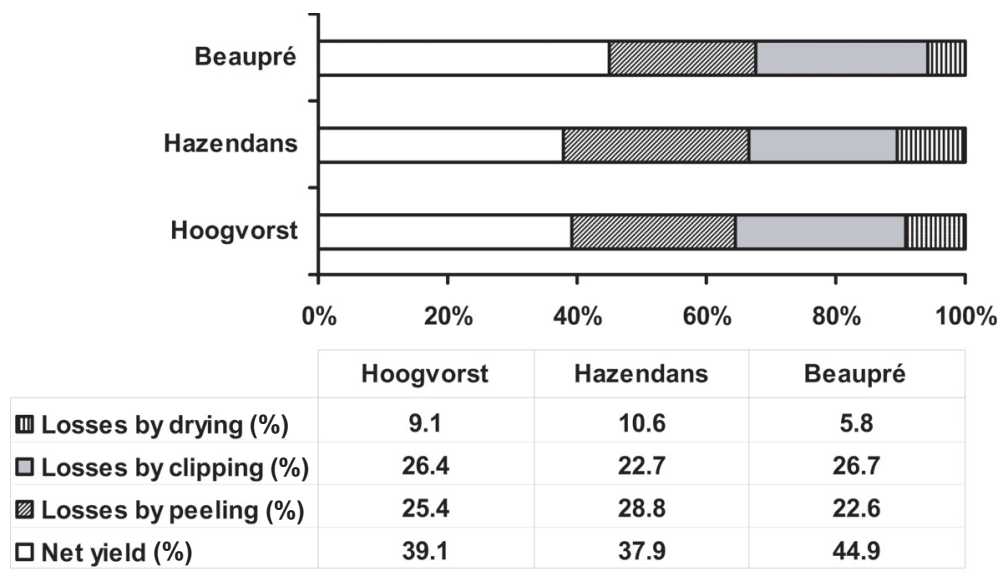

Figure 4. Volume efficiency and losses during manufacturing of veneers disregarding the end-quality.

Table V. Assessment of the veneer quality and detailed information on losses and yields.

\begin{tabular}{|c|c|c|c|c|c|c|c|c|}
\hline & \multicolumn{8}{|c|}{ Veneer quality (\%) } \\
\hline & \multicolumn{3}{|c|}{ A-quality } & \multicolumn{3}{|c|}{ B-quality } & $\mathrm{C} / \mathrm{D}$ quality & Total \\
\hline & White & Striped & Total & White & Striped & Total & Total & \\
\hline Beaupré & 12.6 & 3.9 & 16.5 & 10.7 & 3.9 & 14.6 & 13.8 & 44.9 \\
\hline Hazendans & 0.9 & 0.0 & 0.9 & 16.2 & 0.0 & 16.2 & 20.8 & 37.9 \\
\hline \multirow[t]{4}{*}{ Hoogvorst } & 0.6 & 3.5 & 4.1 & 4.1 & 3.5 & 7.6 & 27.4 & 39.1 \\
\hline & \multicolumn{8}{|c|}{ Loss of veneer $(\%)$} \\
\hline & \multicolumn{3}{|c|}{ Loss by clipping } & \multicolumn{3}{|c|}{ Loss by drying } & \multirow{2}{*}{\multicolumn{2}{|c|}{ Total }} \\
\hline & Holes & Cracks & Total & Cracks & Waviness & Total & & \\
\hline Beaupré & 37.5 & 7.8 & 45.3 & 3.9 & 5.9 & 9.8 & 55.1 & \\
\hline Hazendans & 39.1 & 3.2 & 42.3 & 0.0 & 19.8 & 19.8 & 62.1 & \\
\hline Hoogvorst & 41.0 & 4.3 & 45.3 & 0.0 & 15.6 & 15.6 & 60.9 & \\
\hline
\end{tabular}


Table VI. Density $\left(\mathrm{kg} / \mathrm{m}^{3}\right)$, modulus of elasticity and modulus of rupture $\left(\mathrm{N} / \mathrm{mm}^{2}\right)$ for a 7-layer plywood for each of the selected clones.

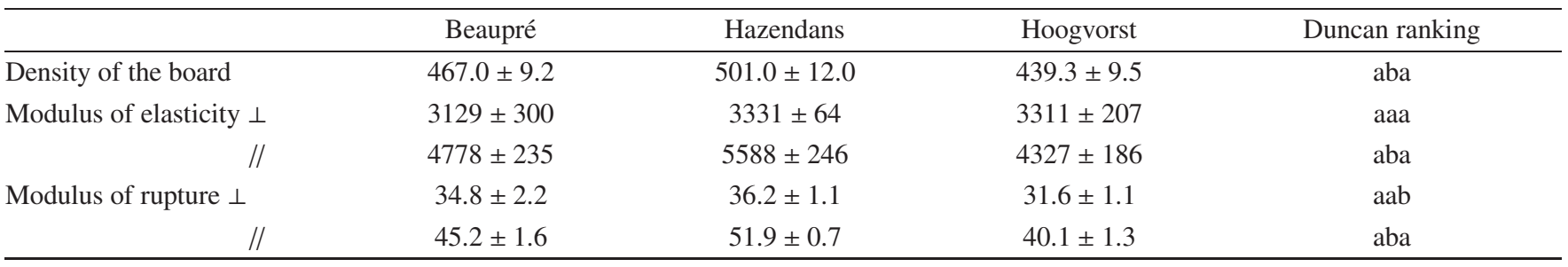

The densification, i.e. the density of the raw material versus the density of the pressed board, is higher for 'Hazendans' and 'Hoogvorst' (12\%) in comparison with 'Beaupré' (10\%). For this reason the strength values of the 'Hazendans' plywood are slightly higher than those of 'Beaupré'. An inverse trend was shown for the strength properties of the solid wood.

\section{DISCUSSION}

\subsection{Influence of growth rate and genetic background}

The clone 'Hoogvorst' has a radial growth rate that is 20 to $25 \%$ higher than 'Beaupré' and 'Hazendans' (Tab. I). Although a trend in decreasing density, modulus of elasticity and modulus of rupture with an increasing radial growth rate can be discerned, no significant correlation could be found between growth features and physical mechanical properties. Hernández [10] and Pliura [19] found a significant but weak negative correlation between radial increment and density. Several features have an influence on this correlation. Firstly, the data set used here represent only a narrow range, both in growth rate and density, which is insufficient to detect significant trends. Diffuse porous species, such as poplar, generally display only a weak response in density to changing growth rates. Finally, the presence of tension wood tends to increase the local density, irrespectively of growth rate.

Zobel and Jett [26] state that for several important wood characteristics (i.e. heartwood formation, density and fibre length), a genetic control has been demonstrated. Klasnja et al. [13] reported a coefficients of heritability of 0.94 for density and 0.61 for mean fibre length in Populus deltoides clones. The investigated clones are genetically closely related ('Beaupré' and 'Hoogvorst' have the same mother and 'Hoogvorst' and 'Hazendans' have the same father). Some caution remains, however, with respect to conclusion concerning the heritability effect, because the crossing between clones V471 and S1-173 is missing in the experiment (Tab. I). The latter crossing was rejected earlier in the selection stage due to lower disease resistance and eccentric stem form. Some of the variations in wood properties, have nevertheless, been interpreted in terms of parental background.

In relative terms, the clone 'Hazendans' produces $30 \%$ more heartwood than 'Hoogvorst' and 'Beaupré'. This indicates a positive genetic influence of the mother clone in 'Beaupré' and 'Hoogvorst' in lowering the heartwood proportion.
Although the mean values for tension wood proportions presented in table II are not discerned by a Duncan range test, the distribution of surface proportion of individual tension wood zones differs for 'Beaupré' in comparison to the other clones. As has been shown in Figure 4, 'Hoogvorst' and 'Hazendans' present a more aggregated presence of tension wood. This might be attributed to an influence of their mutual father clone.

Density is a very strong inheritable feature $[13,26]$. However, the Duncan multiple range test groups the genetically most different clones ('Beaupré' and 'Hazendans') in our study (Tab. III). It seems likely, therefore, that the interclonal differences in density are determined mainly by differences in growth dynamics. The lower density of the clone 'Hoogvorst' can indeed be explained by its more rapid growth since this may produce thinner cell wall structures. Thus, at the same growth rate, all three clones are expected to yield similar density values. These results differ from the findings of Zhang et al. [25], who reported that clonal effects on wood density were stronger than growth trait effects. However, this conclusion was based on very young trees (3-year-old material).

Concerning shrinkage behaviour, contrasting conclusions could be drawn respectively for the ranges of interior and exterior applications. Under low relative air humidity conditions, wood from 'Beaupré' and 'Hoogvorst', which have the same mother, behaves similarly (Tab. IVb). Conversely, under higher relative air humidity conditions, wood from 'Hazendans' and 'Hoogvorst' (same father) displays similar dimensional stability (Tab. IVa). This apparent switch in parental influence may be due to genetically determined differences in the chemical composition and the moisture sorption behaviour of the wood cell walls.

According to Zobel and Jett [26], it is possible to genetically select poplars for a lower degree of heartwood discoloration. The mother clone of 'Beaupré' and 'Hoogvorst' appears to have a negative influence on the whiteness of the veneer sheets. The influence is lower in 'Beaupré' than in 'Hoogvorst' (Tab. V).

\subsection{Relationships between tension wood proportion, heartwood and physical-mechanical properties}

An important feature in the industrial processing of poplar wood remains the occurrence of tension wood fibres and their distribution within the stem volume. The formation of tension wood is induced by a gravitational stimulus [5]. 
This was experimentally proven by Jourez et al. [11] for $P$-euramericana cv 'Ghoy'. Badia et al. [1,2] reported different patterns of tension wood distribution between clones. They also stated that tension wood extent is highest at the tree base, which is also reflected in the data presented in Table II. The variation in the amount of tension wood fibres can vary as much as $22 \%$ to $63 \%$ [7, 17]. In terms of spatial distribution, tension wood occurrence is more diffuse in 'Beaupré' (Fig. [3]) than it is in the other two clones, resulting in flatter drying of the veneer sheets, i.e. a lesser degree of waviness (Tab. V).

'Beaupré' and 'Hazendans' have a relatively higher linearly increase of density with height (respectively \pm 11 and $\left.\pm 9 \mathrm{~kg} / \mathrm{m}^{3}\right)$ than 'Hoogvorst' $\left( \pm 7 \mathrm{~kg} / \mathrm{m}^{3}\right)$ (Tab. III). This is explained by the fact that the heartwood proportions (Tab. II) as well as the ratio of heartwood to sapwood density differ for each clone. For 'Beaupré' this mean ratio is 0.94 meaning that heartwood density is lower than sapwood density. In combination with a rapid decrease of heartwood proportion with height (Tab. II), this results in a more rapid increase of density with height. For 'Hoogvorst' and 'Hazendans', the mean ratios are respectively 1.05 and 1.02 , meaning that heartwood is slightly denser than sapwood. For the clone 'Hazendans', this density ratio combined with its high amount of heartwood results in a comparatively fast increasing density with height. Due to the lower heartwood proportion and the slower decrease of heartwood proportion with height in 'Hoogvorst', the increase in density is less pronounced.

The relation between density and mechanical properties (MOE and MOR) at different heights is graphically represented in Figure 5.

The modulus of elasticity is strongly $(p=0.05)$ positively correlated with density. This trend is significant at the clonal level as well as at the interclonal level. The modulus of rupture increases also with increasing density, but this holds only at the clone level.

At the interclonal level, density does not allow to explain variation in MOR. In fact, 'Hoogvorst' which has the lowest density (Tab. IIIa), exhibits the highest mean values for MOR (Tab. IIIc). Moreover, 'Hoogvorst' has the highest ratio (MOR/density) i.e. 0.19 (0.16 for 'Hazendans' and 0.15 for 'Beaupré'). This implies the existence of a additional influencing factor. Different authors described the clonal influence on fibre length $[4,9,16]$. Fibre length does not have a significant or consistent influence on density [8], but will likely affect the maximal load capacity (i.e. MOR).

At every moisture content, density is significantly ( $p=$ 0.05 ) correlated with the volumetric shrinkage for the interval of $60 \%$ to $40 \%$ RH. For other intervals no significant correlations could be found.

The overall shrinkage values are clearly lower in comparison to earlier reported data $[14,15]$ for other clones, allowing to conclude that the wood of these inter-American clones is more stable. A more profound classification of wood of these clones should be made with regard to their possible end-use. In fact, the evaluation of dimensional stability is depending on the application corresponding with a specific range in $\mathrm{RH}$. Differences in absolute volumetric shrinkage between clones lie within 0.5 to $1.0 \%$ for exterior applications (90-60\% $\mathrm{RH}$ ) and interior applications (60-40\% RH), but the differences in shape factor are more important. Based on that shape factor, 'Beaupré' seems the best clone, both for interior and exterior applications (Tab. IV). Basing on these results, 'Hazendans' seems to be the least suited for interior applications, while 'Hoogvorst' is the least suited for exterior use.

The positive correlations between density and volumetric shrinkage between $60 \%$ and $40 \%$ RH allow to rank poplar clones for their suitability for interior applications, since wood density can be determined relatively easy and fast. On the other hand, for outdoor applications the specific shrinkage or swelling values have to be determined.

\subsection{Potential of veneer based products}

Compared to the traditional ones, all tested clones show an acceptable net efficiency in veneer peeling, although the losses are distributed differently due to several causes (Tab. V).

All clones have high clipping losses due to holes (unacceptable big knots or loose knots). This can be reduced significantly by an adapted tree management, including pruning at early age. The losses due to crack formation after peeling are higher in 'Beaupré'. This is due to the release of internal growth stresses which can not be solved by tree management nor production parameters. Higher internal tensions also may explain the relatively high losses due to cracks formed during drying ( $40 \%$ of the total drying losses). The clonal differences in veneer losses due to drying defects narrows the potential use of poplar clone mixtures as one source of raw material in veneer products. An adaptation of the drying process may partially prevent such losses.

The spatially more diffuse tension wood in 'Beaupré' (Fig. 3) explains the lower amount of waviness after drying, when compared to the other clones. The smaller range in density values of this clone (Tab. III), also contributes to this effect.

White colour of poplar veneer sheets is important in esthetical applications. Therefore, the darkening and striping of wood caused by heartwood discoloration, depreciates veneer quality $[6,23]$. This type of wood is less suitable for furniture production, visible structural applications or applications where a printable surface is required (packaging material and fruit boxes). Overall, only 'Beaupré' and 'Hazendans' produce an acceptable amount of white veneers, i.e. around $20 \%$. White veneer yield may be enhanced by pruning, especially in 'Beaupré', but this will result only in a minor improvement in 'Hazendans' and 'Hoogvorst' due to their un favourable heartwood proportion and distribution.

For all clones, the board properties reported in Table VI are well within range to produce plywood for structural applications. Variations in plywood properties are expected to be lower when mixtures of veneers (different clones and/or qualities) are used in the production process (with a accurate grading of the mixed veneers and corresponding layered structure of the plywood). 


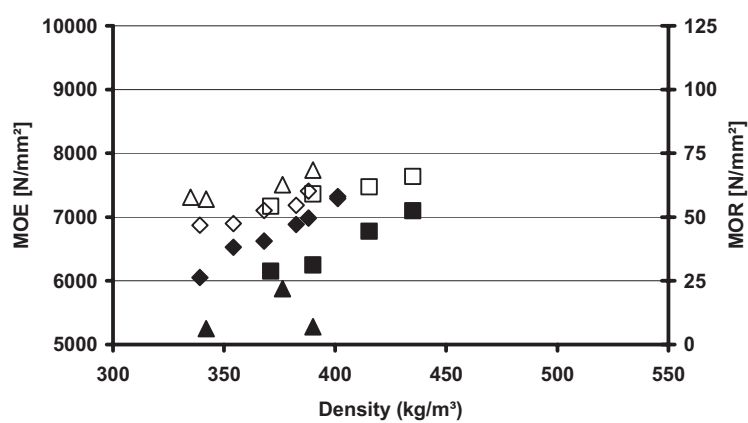

(a)

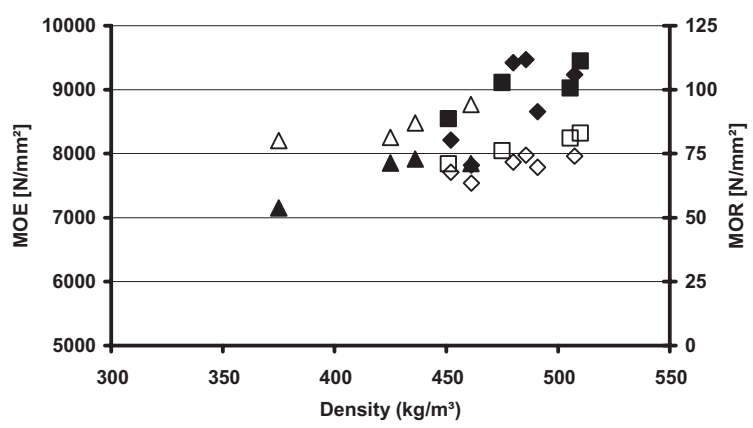

(c)

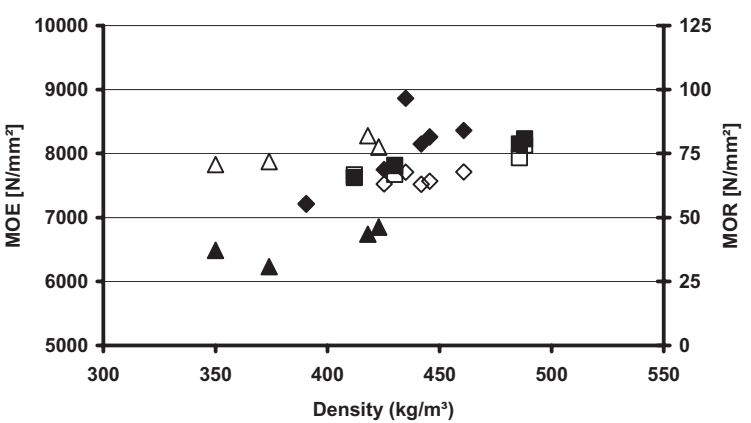

(b)

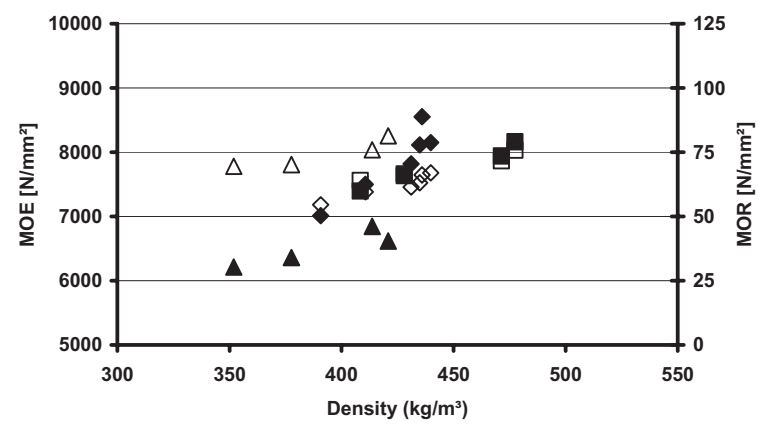

(d)

$\diamond$ MOE Beaupré
$\diamond$ MOR Beaupré

MOE Hazendans $\triangle$ MOE Hoogvorst

MOR Hazendans $\triangle$ MOR Hoogvorst

Figure 5. Relation between density and Modulus of elasticity (MOE) and Modulus of rupture (MOR) for the investigated clones at three different heights (breast height (a); at $6.5 \mathrm{~m} \mathrm{(b)}$; at $11.5 \mathrm{~m} \mathrm{(c))} \mathrm{and} \mathrm{their} \mathrm{volume} \mathrm{weighted} \mathrm{averages} \mathrm{for} \mathrm{the} \mathrm{whole} \mathrm{stem} \mathrm{up} \mathrm{to} 11.5 \mathrm{~m}$ (d).

\subsection{Main conclusions}

It can be concluded that 'Beaupré' is suitable for both plywood and sawn wood production. 'Hazendans' has good average characteristics supporting its use in sawn wood based products. Its yield of white veneers is sufficient for the production of plywood in esthetical applications. The clone 'Hoogvorst' produces too few white veneers, restricting the use of its veneers to structural plywood manufacturing. The larger values found for the shape factor in this clone may limit its use in sawn wood based products.

Further research on clonal variation in properties is needed to assess adequate processing strategies for multiclonal poplar stands (extending the number of sampled trees and the number of stands).

Acknowledgements: This study has been financed by the Institute of Nature and Forest Research (INBO - Geraardsbergen, Belgium) of the Ministry of the Flemish Community within the framework of the project "Tree and wood Quality Research for the Flemish ForestWood Chain".

\section{REFERENCES}

[1] Badia M.A., Constant T., Mothe F., Nepveu G., Tension wood occurrence in three cultivars of Populus $\times$ euramericana, Part I: Interclonal and intra-tree variability of tension wood, Ann. For. Sci. 63 (2006) 23-30.

[2] Badia M.A., Mothe F., Constant T., Nepveu G., Assessment of tension wood detection based on shiny appearance for three poplar cultivars, Ann. For. Sci. 62 (2005) 43-49.

[3] Beaudoin M., Hernández R.E., Koubaa A., Poliquin J., Interclonal, intraclonal and within-tree variation in wood density of poplar hybrid clones, Wood Fiber Sci. 24 (1992) 147-153.

[4] Castera P., Nepveu G., Mahe F., Valentin G., A study of growth stresses, tension wood distribution and other related wood defects in poplar (Populus euramericana cv I214) - end splits, specific gravity and pulp yield, Ann. For. Sci. 51 (1994) 301-313.

[5] Clair B., Almeras T., Sugiyama J., Compression stress in opposite wood of angiosperms: observations in chestnut, mani and poplar, Ann. For. Sci. 63 (2006) 507-510.

[6] Clausen V.H., Kaufert F.A., Occurrence and probable cause of heartwood degradation in commercial species of Populus, J. For. Prod. Res. Soc. 2 (1952) 62-67.

[7] Coutand C., Jeronimidis G., Chanson B., Loup C., Comparison of mechanical properties of tension and opposite wood in Populus, Wood Sci.Tech. 38 (2004) 11-24. 
[8] Debell D.S., Singleton R., Harrington C.A., Gartner B.L., Wood density and fiber length in young Populus stems: Relation to clone, age, growth rte and pruning, Wood Fiber Sci. 34 (2002) 529-539.

[9] Dix B., Roffael E., Becker G., Gruss K., Properties of pulps prepared from poplar wood of different clones, sites and ages, Papier 46 (1992) 583-592.

[10] Hernández R.E., Koubaa A., Beaudoin M., Fortin Y., Selected mechanical properties of fast-growing poplar hybrid clones, Wood Fiber Sci. 30 (1998) 138-147.

[11] Jourez B., Vaianopoulos C., Hebert J., Effect of intensity of gravitational stimulus artificially induced on growth and tension wood formation in young shoots of poplar (P. euramericana cv 'Ghoy'), Ann. Sci. For. 60 (2003) 789-802.

[12] Karki T., Variation of wood density and shrinkage in European aspen (Populus tremula), Holz Roh-u. Werkst. 59 (2001) 79-84.

[13] Klasnja S., Kopitovic S., Orlovic S., Variability of some wood properties of eastern cottonwood (Populus deltoides Bartr.) clones, Wood Sci. Tech. 37 (2003) 331-337.

[14] Kopitovic S., Klasnja B., Guzina V., Orlovic S., Structural-physical characteristics and chemical composition of wood of some Hybrid progenies of eastern cottonwood ( $P$. deltoides Bartr.), Drevàrsky Výskum 41 (1996) 23-34.

[15] Koubaa A., Hernández R.E., Beaudoin M., Shrinkage of fastgrowing hybrid poplar clones, For. Prod. J. 48 (1998) 82-87.

[16] Koubaa A., Hernández R.E., Beaudoin M., Poliquin J., Interclonal, intraclonal and within-tree variation in fiber length of poplar hybrid clones, Wood Fiber Sci. 30 (1998) 40-47.

[17] Kroll R.E., Ritter D.C., Gertejansen R.O., Au K.C., Anatomical and physical properties of balsam poplar (Populus balsamifera L.) in Minnesota, Wood Fiber Sci. 24 (1992) 13-24.
[18] Pezlen I., Variation in specific gravity and mechanical properties of poplar clones, Drevàrsky Výskum 43 (1998) 1-17.

[19] Pliura A., Yu Q.B., Zhang S.Y., Mackkay J., Perinet P., Bousquet J., Variation in wood density and shrinkage and their relationship to growth of selected young poplar hybrid crosses, For. Sci. 51 (2005) $472-482$.

[20] Rijsdijk J.F., Laming P.B., Physical and related properties of 145 timbers, Kluwer academic publishers, London, 1994.

[21] Steenackers J., Steenackers M., Steenackers V., Stevens M., Poplar diseases, consequences on growth and wood quality, Biomass Bioenergy 10 (1996) 267-274.

[22] Steenackers J., Steenackers M., Stevens M., Variations in specific gravity within the progeny of two poplar crossings. Relations to rate of growth and disease resistance, IUFRO All divisions 5 Conference, Forest Products for Sustainable Forestry, 1997.

[23] Ward J.C., Zeikus J.G., Bacteriological, chemical and physical properties of wetwood in living trees, Mitt. Bundesforsch-anst. Forst- Holzwirtsch. 131 (1980) 133-166.

[24] Yanchuk A.D., Dancik B.P., Micko M.M., Intraclonal variation in wood density of trembling aspen in Alberta, Wood Fiber Sci. 15 (1983) 387-394.

[25] Zhang S.Y., Yu Q.B., Chauret G., Koubaa A., Selection for both growth and wood properties in hybrid poplar clones, For. Sci. 49 (2003) 901-908.

[26] Zobel B.J., Jett J.B., Genetics of Wood Production, Springer Verlag, Berlin, Heidelberg, New York, 1995. 